\title{
PERBAIKAN PRESTASI BELAJAR IPA MELALUI PENERAPAN MODEL PEMBELAJARAN KOOPERATIF TIPE STAD (STUDENT TEAM ACHIEVEMENT DIVISION) KELAS VI SD NEGERI 034 PINTUPADANG JULU
}

\author{
Asliana \\ Guru SD Negeri 034 Pintupadang Julu \\ Surel : asliana@gmail.com
}

\begin{abstract}
Abstrak
Penelitian ini menerapkan model pembelajaran kooperatif tipe STAD sebagai upaya perbaikan prestasi belajar siswa pada mata pelajaran IPA. Hasil penelitian menunjukkan Siklus I : menulis/membaca (45\%), Mengerjakan LKS $(14 \%)$, bertanya sesama teman $(12 \%)$, bertanya kepada guru $(17 \%)$, dan yang tidak relevan dengan KBM (13\%). Dan Data aktivitas siswa menurut pengamatan pada siklus II : menulis/membaca (27\%), mengerjakan LKS (40\%), bertanya sesama teman $(21 \%)$, bertanya kepada guru $(8 \%)$, dan yang tidak relevan dengan KBM (4\%); 2) Dengan menerapkan model pembelajaran kooperatif Tipe STAD prestasi belajar siswa dari siklus ke siklus berikutnya mengalami peningkatan yaitu dengan persentase ketuntasan klasikal sebesar 67,78\%. Pada Siklus II, ketuntasan klasikal $100 \%$, niali hasil capaian belajar siswa rata-rata siklus I dan siklus II adalah 65,8 dan 86,32 .
\end{abstract}

Kata Kunci : Model, Kooperatif Tipe STAD

\section{PENDAHULUAN}

Suatu pembelajaran dikatakan berhasil apabila terjadi perubahan tingkah laku positif pada peserta didik sesuai dengan tujuan pembelajaran yang telah direncanakan. Pada umumnya kegiatan pembelajaran bergantung pada guru sebagai elemen penting yang mengatur proses belajar mengajar. Guru yang bertanggungjawab seharusnya selalu proaktif dan responsif terhadap semua fenomena - fenomena yang dijumpai di kelas. Oleh karena itu guru tidak hanya sebagai penerima pembaharuan pendidikan, namun ikut bertanggungjawab dan berperan aktif dalam melakukan pembaharuan pendidikan serta mengembangkan pengetahuan dan keterampilan melalui penelitian tindakan dalam pengelolahan pembelajaran di kelasya.

Berdasarkan analisa peneliti terhadap kinerja peneliti sebagai guru masih banyak kekurangankekurangan yang peneliti lakukan selama pembelajaran. Peneliti lebih dominan mengajar dengan menggunakan metode ceramah. Menurut peneliti metode ceramah, adalah metode yang paling efesian di gunakan selama pembelajaran, dimana guru menjadi sumber informasi dan siswa dapat langsung 
memperoleh ilmu dari penjelasan yang di berikan oleh guru. Memang hasil belajar siswa kurang memuaskan di setiap ulangan khususnya pada mata pelajaran IPA. Berdasarkan uji kemampuan awal siswa kelas VI pada mata pelajaran IPA, Hanya $13,15 \%$ siswa yang lulus KKM yang ditetapkan tanpa harus mengikuti remedial. Hal ini cukup mengecewakan bagi peneliti namun, peneliti tetap mempertahankan metode mengajar peneliti dengan harapan hasil belajar siswa akan membaik nantinya.

Setelah mengikuti
pembimbingan dan pelatihan
pembuatan penelitian tindakan kelas

yang dilakukan atas kerjasama Widyaiswara LPMP sumut dan juga dosen dari UNIMED yang berlokasi di lingkungan UPT Dinas Pendidikan kecamatan Siabu Kabupaten Mandailing Natal, peneliti menyadari bahwa peneliti telah melakukan kesalahan dengan cara-cara mengajar yang selama ini berupa pembelajaran konvensional. Kurang memuaskannya hasil belajar siswa adalah maslah yang segera peneliti harus atasi. Hal paling sederhana yang dapat peneliti lakukan adalah dengan menerapkan model - model pembelajaran sebagai inovasi pembelajaran yang memang sudah menjadi kewajiban peneliti.

Inovasi dalam pembelajaran adalah dengan mengikutsertakan siswa ke dalam pembelajaran ataupun menciptakan suasana belajar yang aktif bagi siswa. Salah satu model pembelajaran yang mengikutsertakan siswa dalam pembelajaran dalah model pembelajaran kooperatif. Pembelajaran kooperatif lebih menekankan interaksi antar siswa. Dari sini siswa akan melakukan komunikasi aktif dengan sesama temannya. Dengan komunikasi tersebut diharapkan siswa dapat menguasai materi pelajaran dengan mudah karena "siswa lebih mudah memahami penjelasan dari kawannya dibanding penjelasan dari guru, karena taraf pengetahuan serta pemikiran mereka lebih sejalan dan sepadan".

Dalam penelitian ini peneliti akan menerapkan model pembelajaran kooperatif selama pembelajaran. Model pembelajaran kooperatif yang peneliti terapkan yakni model pembelajaran kooperatif tipe STAD (Student Team Achievment Division). Model pembelajaran tipe STAD dapat meningkatkan semangat belajar siswa untuk lebih tertarik terhadap mata pelajaran dan keingintahuannya rendah bisa menjadi lebih tinggi, mengidikasikan bahwa ketertarikan siswa terhadap pelajaran karena keingintahuannya. Ini merupakan efek dari Model Pembelajaran Kooperatif Type STAD yang cukup menumbuhkan sikap ingin tahu dan minat terhadap pelajaran. Sementara efek pembelajaran kooperatif sangat terlihat dari tingginya keinginan untuk saling membantu dalam pembelajaran. 
Berdasarkan permasalahan pada latar belakang, maka yang menjadi identifikasi masalah dalam meningkatkan hasil belajar IPA melalui Model Pembelajaran Kooperatif Tipe STAD (Student Team Achievment Division) antara lain:

1. Pembelajaran masih berpusat pada guru.

2. Guru mengajar dengan metode konvensional tidak menerapkan metode atau model pembelajaran yang bervariasi

3. Siswa kurang terlibat dalam proses pembelajaran.

4. Siswa belum aktip dalam pembelajaran IPA

5. Pemahaman siswa terhadap mata pelajaran IPA masih rendah.

\section{Setelah}

menetapkan identifikasi masalah hasil belajar, maka rumusan masalah dalam penelitian ini antara lain:

1. Apakah aktivitas belajar siswa meningkat dengan diterapkannya model pembelajaran kooperatif tipe STAD (Student Team Achievment Division) pada mata pelajaran IPA di kelas VI SD Negeri 034 Pintupadang Julu Tahun Pembelajaran 2014/2015?

2. Apakah prestasi belajar siswa meningkat setelah diterapkannya model pembelajaran kooperatif tipe

STAD (Student Team

Achievment Division) pada mata pelajaran IPA di kelas VI SD Negeri 034 Pintupadang Julu Tahun Pembelajaran 2014/2015?

Dalam penelitian ini yang menjadi metode pemecahan masalah adalah diterapkannya model pembelajaran kooperatif tipe STAD (Student Team Achievment Division) selama pembelajaran. Dengan penerapan model pembelajaran ini diharapkan hasil belajar dan juga aktivitas belajar siswa akan meningkat.

Setelah menetapkan rumusan masalah di atas maka, dapat ditentukan tujuan penelitian ini, antara lain:

1. Untuk mengetahui apakah prestasi belajar siswa meningkat setelah diterapkannya model pembelajaran kooperatif tipe STAD (Student Team Achievment Division) pada mata pelajaran IPA di kelas VI SD Negeri 034 Pintupadang Julu Tahun Pembelajaran 2014/2015.

2. Untuk mengetahui apakah aktivitas belajar siswa meningkat dengan diterapkannya model pembelajaran kooperatif tipe STAD (Student Team Achievment Division) pada 
mata pelajaran IPA di kelas

VI SD Negeri 034

Pintupadang Julu Tahun

Pembelajaran 2014/2015.

Penelitian ini diharapkan dapat memberikan manfaat sebagai berikut:

1. Meningkatkan prestasi belajar siswa

2. Memberikan pengalaman secara nyata kepada siswa melalui model pembelajaran kooperatif tipe STAD.

3. Meningkatkan aktivitas belajar siswa.

4. Sebagai bahan masukan bagi pihak sekolah, khususnya para guru mengenai model pembelajaran kooperatif tipe STAD (Student Team Achievment Division).

5. Sebagai bahan masukan bagi peneliti yang ingin melakukan penelitian sejenis.

\section{METODOLOGI PENELITIAN}

Penelitian ini dilakukan di SD Negeri 034 Pintupadang Julu di Desa Pintupadang Julu, kecamatan Siabu, Kabupaten Mandailing Natal, dan pelaksanaannya pada September 2014 sampai dengan Desember 2014 Tahun Pembelajaran 2014/2015.

Subjek penelitian ini adalah seluruh siswa kelas VI SD Negeri 034 Pintu Padang Julu. Dengan mempertimbangkan peneliti adalah guru kelas VI, maka subjek yang digunakan dalam penelitian ini adalah seluruh siswa kelas VI Tahun Pelajaran 2014/2015, dengan jumlah siswa seluruhnya sebanyak 38 orang.

Hasil belajar siswa adalah hasil yang telah dicapai setelah melakukan atau mengerjakan sesuatu dalam kegiatan pembelajaran.

Penelitian Tindakan Kelas (PTK) ini dilakukan dalam 2 siklus, sesuai dengan waktu yang telah direncanakan, yakni 8 jam pelajaran yang dilaksanakan sebanyak 4 kali pertemuan untuk pokok bahasan sebagai berikut :

1. Materi pembelajaran siklus I :

a. Kegiatan Pembelajaran

Perkembangbiakan pada hewan dengan membelah diri dan bertunas

b. Kegiatan Pembelajaran

Perkembangbiakan pada hewan Ovivar

2. Materi pembelajaran siklus II :

a. Kegiatan Pembelajaran 1 Perkembangbiakan hewan Vivivar

b. Kegiatan Pembelajaran 2 Perkembangbiakan pada hewan Ovovivivar

Pada tiap putaran terdiri atas 4 tahap, yaitu : 
1. Rancangan

2. Kegiatan dan pengamatan

3. Refleksi

4. Revisi

Adapun putaran dari pelaksanaan penelitian tindakan kelas dapat digambarkan sebagai berikut :

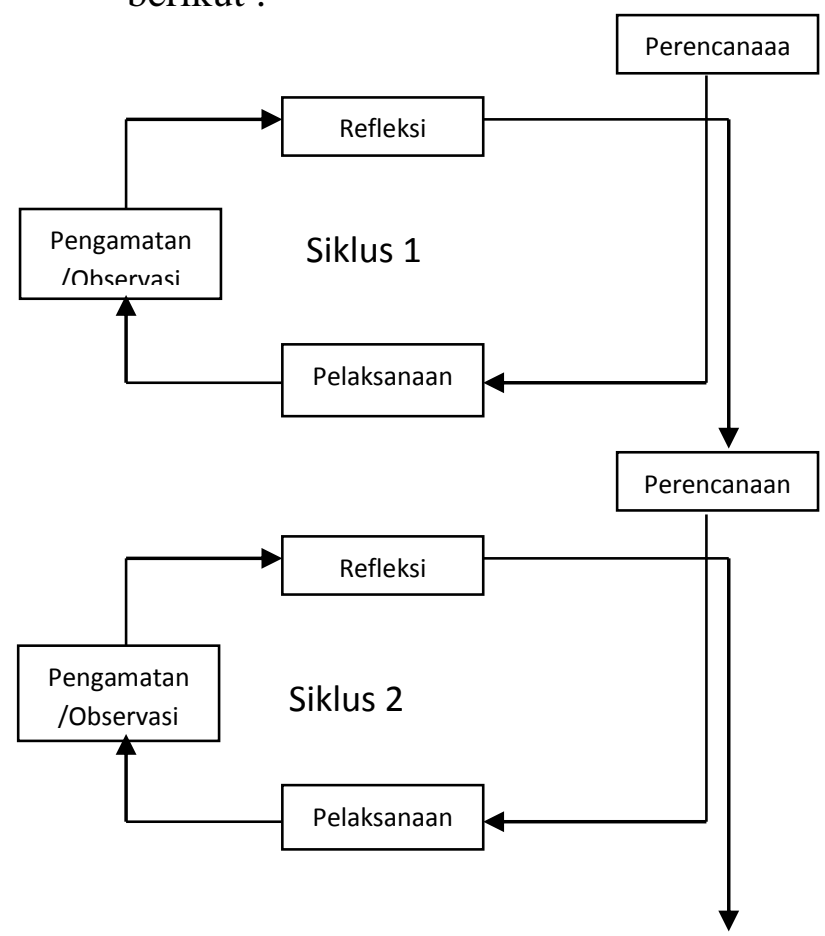

Gamb 3.1 : Alur Penelitian

Tindakan Kelas(Tim PGSM, 1999)

Prosedur penelitian tindakan kelas ditempuh dalam 2 (dua) siklus kegiatan. Tahapan-tahapan tersebut adalah sebagai berikut:

\section{A. Siklus I}

Kegiatan pada Siklus I meliputi:

1) Perencanaan Tindakan

Pada tahap ini peneliti berdiskusi secara kolaboratif dengan guru mata pelajaran sejenis dan pembimbing serta nara sumber dosen dari UNIMED dengan kegiatan perencanaan meliputi:

a) Penyusunan rencana pelaksanaan pembelajaran dan lembar kegiatan siswa yang telah dibuat oleh guru tentang sub materi perkembangbiakan hewan dengan membelah diri dan bertunas (KBM 1), perkembangbiakan pada hewan Ovivar (KBM 2). Selanjutnya diubah atau ditambah sesuai dengan model pembelajaran kooperatif tipe STAD

b) Penyusunan instrumen penelitian berupa lembar observasi aktivitas siswa serta pengelolaan guru terhadap proses pembelajaran dengan menerapkan model pembelajaran kooperatif tipe STAD dan tes pemahaman siswa tentang hasil belajar siswa.

2) Pelaksanaan Tindakan dan Observasi (Action and Observation)

Melaksanakan tindakan pembelajaran ke-1 dan ke-2 sesuai dengan RPP oleh peneliti sebagai guru di kelas VI Selama proses pembelajaran dilakukan observasi oleh observer (guru sejawat) untuk mengamati aktivitas siswa dan pengelolaan pembelajaran oleh guru. Diakhir siklus I dilakukan pula tes hasil belajar siswa untuk mengetahui pemahaman siswa tentang sup 
materi yang diajarkan sebagai formatif I.

3) Refleksi (Reflective)

Kegiatan refleksi dilakukan oleh peneliti dengan kolaborator berdasarkan hasil observasi dan evaluasi hasil pembelajaran IPA di kelas VI dengan menerapkan model pembelajaran kooperatif tipe STAD. Dari hasil refleksi kemudian peneliti berkolaborasi dengan guru mata pelajaran sejenis dan pembimbing serta nara sumber dosen dari UNIMED untuk memperbaiki dan menguatkan rencana tindakan siklus II.

B. Siklus II

Kegiatan pada siklus II meliputi:

1) Perencanaan Tindakan

Berdasarkan hasil refleksi terhadap proses pembelajaran pada siklus I maka pada siklus II disusun skenario model pembelajaran kooperatif tipe STAD dengan revisi tindakan untuk memperbaiki proses. Peneliti berdiskusi secara kolaboratif dengan guru mata pelajaran sejenis dan pembimbing serta nara sumber dosen dari UNIMED dengan kegiatan perencanaan meliputi:

a) Penyusunan rencana pelaksanaan pembelajaran dan lembar kegiatan siswa yang telah dibuat oleh guru tentang sub materi perkembangbiakan pada hewan Vivivar (KBM 3), dan perkembangbiakan pada hewan Ovovivivar (KBM 4).

b) Penyusunan instrumen penelitian berupa lembar observasi aktivitas siswa serta pengelolaan guru terhadap proses pembelajaran dengan menerapkan model pembelajaran kooperatif tipe STAD dan tes pemahaman siswa tentang indikator materi yang di ajarkan pada siklus II.

2) Pelaksanaan Tindakan dan Observasi (Action and Observation)

Melaksanakan tindakan pembelajaran ke-3 dan ke-4 sesuai dengan RPP model pembelajaran kooperatif oleh peneliti sebagai guru IPA di kelas VI. Selama proses pembelajaran dilakukan observasi oleh observer (guru sejawat) untuk mengamati aktivitas siswa dan pengelolaan pembelajaran oleh guru. Diakhir siklus II dilakukan pula tes hasil belajar untuk mengahui pemahaman siswa tentang hasil belajar siswa pada indikator materi siklus II sebagai formatif II.

3) Refleksi (Reflective)

Setelah kegiatan pembelajaran siklus II dilaksanakan, dilanjutkan dengan kegiatan refleksi oleh peneliti berkolaborasi guru mata pelajaran sejenis dan pembimbing serta nara. Berdasarkan hasil observasi aktivitas siswa dalam 
pembelajaran dan ketuntasan hasil belajar siswa ditelaah.

Instrumen penelitian disusun melalui diskusi kolaborasi antara peneliti dengan guru sejawat, pembimbing, dan nara dosen dari UNIMED. Perangkat siklus I disusun dalam perencanaan siklus I. Sementara dalam Siklus II perangkat disusun dalam perencanaan siklus II, ini dimaksudkan agar teridentifikasi kelemahan pembelajaran dan tersusun rencana yang direvisi terlebih dahulu. Instrumen yang digunakan dalam penelitian ini terdiri dari:

\section{Lembar Observasi Kegiatan Belajar Mengajar}

Istrumen ini terdiri dari lembar observasi aktivitas siswa dalam pembelajaran. Lembar observasi aktivitas siswa, untuk melihat aktivitas belajar siswa selama proses pembelajaran IPA tiap siklus.

\section{Tes formatif}

Tes digunakan untuk mengetahui hasil belajar siswa sebelum dan sesudah pembelajaran dengan model kooperatif tipe STAD. Tes disusun dalam bentuk soaal essay yang mengacu pada Kurikulum Tingkat Satuan Pendidikan (KTSP) untuk kelas VI bidang studi IPA. Tes yang digunakan sebanyak 10 item. Tes tersebut dituangkan dalam bentuk tabel spesifikasi seperti tercantum pada Tabel 3.1 di bawah ini.
Tabel 3.1 : Tabel Kisi-Kisi Tes Hasil Belajar

\begin{tabular}{|c|c|c|c|c|}
\hline No & Indikator & $\begin{array}{c}\text { Bentuk } \\
\text { Soal }\end{array}$ & Skor & $\begin{array}{c}\text { Tingkat } \\
\text { Kognitif }\end{array}$ \\
\hline 1. & & Essay & 1 & $\mathrm{C} 1$ \\
\hline 2. & & Essay & 1 & $\mathrm{C} 1$ \\
\hline 3. & & Essay & 1 & $\mathrm{C} 2$ \\
\hline 4. & & Essay & 1 & $\mathrm{C} 1$ \\
\hline 5. & & Essay & 1 & $\mathrm{C} 2$ \\
\hline 6. & & Essay & 1 & $\mathrm{C} 1$ \\
\hline 7. & & Essay & 1 & $\mathrm{C} 2$ \\
\hline 8. & & Essay & 1 & $\mathrm{C} 1$ \\
\hline 9. & & Essay & 1 & $\mathrm{C} 2$ \\
\hline 10. & & Essay & 1 & $\mathrm{C} 1$ \\
\hline
\end{tabular}

Keterangan :

$\mathrm{C}_{1}$ : Pengetahuan

$\mathrm{C}_{2}$ : PemahamanC $\mathrm{C}_{5}$ : Sintesis

$\mathrm{C}_{3}$ : Aplikasi

$\mathrm{C}_{4}$ : Analisis

$\mathrm{C}_{5}$ : Sintesis

$\mathrm{C}_{6}$ : Evalu

Teknik Analisis Data

Metode Analisis Data Pada penelitian ini digunakan metode deskriptif dengan membandingkan hasil belajar siswa sebelum tindakan dengan hasil belajar siswa setelah tindakan.

Langkah-langkah pengolahan data sebagai berikut:

a. Merekapitulasi nilai pretes sebelum tindakan dan nilai tes akhir siklus I dan siklus II

b. Menghitung nilai rerata atau persentase hasil belajar siswa sebelum dilakukan tindakan dengan hasil belajar setelah dilakukan tindakan pada siklus I dan Siklus II untuk mengetahui adanya peningkatan hasil belajar. 


\section{Penilaian}

a. Data nilai hasil belajar (kognitif) diperoleh dengan menggunakan rumus:

KKM secara individual dan $85 \%$ secara klasikal.

Penelitian menggunakan indikator ketercapaian yakni KKM Nilai Siswa $=$ Jumlah jawaban bendBA untuk kelas VI sebesar 60 untuk Jumlah seluruh sodtividu siswa. Artinya siswa dikatakan tuntas belajar jika nilainya

b. Nilai rata-rata siswa dicari dengan rumus sebagai berikut:

$$
\bar{X}=\frac{\sum X}{N}
$$

Keterangan :

$$
\begin{aligned}
& \bar{X}=\text { Nilai rata-rata } \\
& \Sigma=\text { Jumlah nilai } X \\
& \mathrm{~N}=\text { Jumlah peserta tes }
\end{aligned}
$$

c. Untuk penilaian aktivitas digunakan rumus sebagai berikut:

$$
\begin{aligned}
& \% \text { Proporsi Aktivitas } \\
& =\frac{\text { jumlah skor yang diperoleh }}{\text { jumlah skor ideal }} \times 100 \%
\end{aligned}
$$

(Majid, 2009:268)

\section{d. Ketentuan persentase} ketuntasan belajar kelas Ketuntasan belajar kelas $=\frac{\sum S_{b}}{K} \times 100 \%$ $\Sigma \mathrm{Sb}=$ Jumlah siswa yang mendapat nilai $\geq$ KKM

$\Sigma \mathrm{K}=$ Jumlah siswa dalam sampel.

Sebagai tolak ukur keberhasilan penelitian tindakan kelas ini dapat dilihat dari: hasil tes, jika hasil belajar siswa mencapai dalam formatif mencapai KKM ini. Sedangkan kelas dikatakan tuntas atau penelitian berhasil jika paling tidak $85 \%$ dari jumlah siswa dalam kelas subjek memperoleh nilai mencapai KKM.

\section{HASIL PENELITIAN DAN PEMBAHASAN}

Sebelum peneliti melakukan siklus I, maka terlebih dahulu peneliti mengumpulkan data atau kondisi awal siswa sebagai bandingan terhadap kondisi siwa setelah siklus I dengan penerapan model pembelajaran kooperatif tipe STAD. Data hasil pretes siswa menunjukkan rata-rata hasil belajar siswa 42,4 dengan ketuntasan klasikal dan individu 13,15\%. Berdasarkan data pretes siswa dapat diambil simpulan bahwa siswa tidak mempelajari materi yang akan di pelajari di rumah, dan rendahnya rasa ingin tau siswa terhadap pembelajaran. Hasil belajar siswa pada tes awal disajikan pada tabel 4.1 berikut : 
Tabel 4.1 Distribusi Hasil belajar siswa saat tes awal

\begin{tabular}{|c|c|c|c|c|}
\hline Skor & Frekuensi & Rata-rata & $\begin{array}{l}\mathrm{S} \\
\text { Deviasi }\end{array}$ & $\begin{array}{l}\text { K } \\
\text { Klasikal }\end{array}$ \\
\hline 10 & 2 & \multirow{9}{*}{42,4} & \multirow{9}{*}{14,59} & \multirow{9}{*}{$13.15 \%$} \\
\hline 20 & 4 & & & \\
\hline 30 & 1 & & & \\
\hline 40 & 15 & & & \\
\hline 50 & 41 & & & \\
\hline 50 & 11 & & & \\
\hline 60 & 2 & & & \\
\hline 70 & 3 & & & \\
\hline Jumlah & 38 & & & \\
\hline
\end{tabular}

Data hasil belajar pada tabel 4.1 dapat disajikan kembali dalam grafik histogram sebagai berikut:

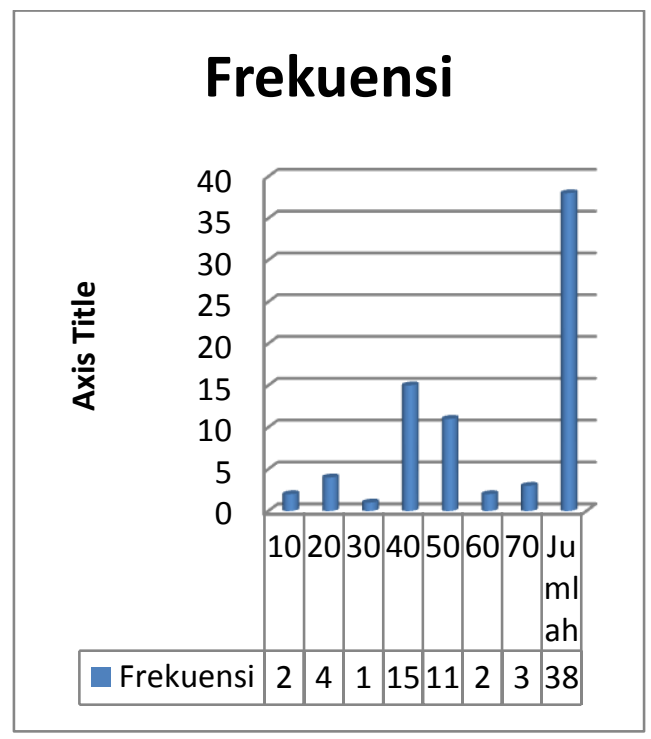

Gambar 4.1. Grafik histogram hasil belajar saat tes awal

\section{Sikuls I}

\section{Rencana}

Hal-hal yang dilakukan dalam perencanaan adalah :

a. Menyiapkan Silabus dan RPP

b. Menyiapkan Materi Pelajaran

c. Menyiapkan Lembar Kegiatan Siswa (LKS 1 dan LKS 2)

d. Menyiapkan soal tes hasil belajar (Formatif I)

e. Menyiapkan lembar pengamatan untuk aktivitas siswa.

\section{Kegiatan dan Pengamatan Kegiatan pembelajaran 1}

Senin pada les ke-8, murid-murid masuk ke kelas masing-masing. Siswa masuk ke kelas dan duduk di bangkunya masing-masing, sehingga ketika peneliti berada dalam ruangan, suasana kelas tertib, dan siswa sudah mengeluarkan buku mata pelajaran IPA.

Sesampainya di meja guru, peneliti memberikan salam kepada siswa,

Assalamu alaikum anak-anak", dan seluruh siswa menjawab salam guru dengan mengucapkan“"Walaikum Salam Bu”. Guru kemudian bertanya, apakah ada siswa yang tidah hadir, dengan serentak siswa menjawab tidak ada Bu...!. Siswa tampak terkejut karena secara tiba-tiba diberi ujian. Guru membagikan soal pretes. Soal pretes terdiri dari 10 soal yang mencakup semua indikator materi yang akan di ajarkan selama 4 KBM. Ujian pretes dilakukan selama 15 menit. Setelah 15 menit waktu ujian guru kemudian meminta seluruh siswa untuk mengumpulkan lembar jawabannya. Siswa mengumpulkan lembar jawaban dan kemudian kembali ke tempat duduk mereka masing-masing.

Peneliti kemudian bertanya pada siswa " sulit soalnya nak ?" tanya guru. Dengan serentak siswa menjawab sulit buk...... beberapa siswa diantaranya : Saleh, khoiruddin, dan Ali Rohman kemudian 
mengeluh jika soal yang diberi belum pernah diajarkan materinya. Peneliti kemudian menjelaskan bahwa itu adalah ujian pretes untuk mengetahui kemampuan awal siswa sebelum mengikuti pembelajaran, setelah itu guru kemudian menyampaikan materi ajar dan menjelaskan tujuan pembelajarannya. Setelah memberikan apersepsi, dan mejabarkan tujuan pembelajaran, guru menjelaskan materi dengan sangat singkat, peneliti memperkenalkan perkembangan makhluk hidup. Kemudian peneliti membagi siswa menjadi 8 kelompok. Setiap kelompok terdiri dari 5 orang. peneliti kemudian membagikan LKS kepada siswa,. Waktu yang diberikan yakni 30 menit. Selama siswa berdiskusi dan mengerjakan LKS, guru bertindak sebagai fasilitator. Saat siswa berdiskusi, dua orang pengamat, mengamati aktivitas belajar siswa.

Setelah 30 menit waktu diskusi, guru memberikan aba-aba kepada siswa, bahwa waktu diskusi sudah habis. Siswa kemudian berhenti berdiskusi, guru kemudian meminta kelompok 1 untuk maju dan membacakan hasil diskusi mereka, guru juga meminta pembuktian dari setiap jawaban mereka. Kelompok 1 maju dan membacakan hasil diskusinya serta memperagakan langsung di depan kelas bahwa jawaban mereka benar. Tiba-tiba terdengar lonceng berbunyi, Pembelajaran ditutup dan bersiap untuk pulang kerumah masing-masing, sebelum meninggalkan kelas guru mengajak siswa berdoa bersamasama.

\section{Kegiatan pembelajaran 2}

KBM 2 dilakukan pada tanggal 7 Nopember 2014. Lonceng berbunyi tanda les ke- 1 dimulai. Peneliti kembali masuk ke kelas VI, sesampainya di kelas VI Peneliti mengucapkan salam " Assalamu alaikum anak-anak", dan seluruh siswa menjawab "walaikum salam Buk". Peneliti kemudian duduk di kursi guru dan berkata, bahwa sekarang adalah mata pelajaran IPA. Siswa mengeluarkan buku pelajaran IPA mereka. Guru kemudian mengingatkan siswa materi sebelumnya yakni : perkembangbiakan pada hewan Ovivar. Guru kemudian memberikan apersepsi mengenai materi untuk lebih merangsang keingintauan siswa, guru juga menjelaskan tujuan pembelajaran kepada siswa. Setelah itu guru membagi siswa menjadi 8 kelompok dan membagikan LKS pada msng-masing kelompok. Siswa kemudian mulai bekerja dan berdiskusi. Waktu diskusi yakni 30 menit. Siswa berdiskusi dengan difasilitaor guru dan pada saat siswa berdiskusi pengamat mengambil data aktivitas belajar siswa. Pada saat siswa berdiskusi sambil melakukan percobaan, masih banyak siswa yang kurang serius. Ada siswa yang bercerita, ada siswa yang mengganggu temannya dan membuat kegaduhan. Setelah pemecahan masalah dilakukan dan LKS di selesaikan oleh siswa, guru kemudian meminta kelompok 2 untuk membacakan hasil diskusi mereka, kelompok 2 maju dan melaksakan apa yang diinstruksikan oleh guru. Setelah selesai, guru bertanya pada siswa, apakah ada hal yang mereka belum mengerti, siswa menjawab tidak ada. Kemudian guru meminta siswa untuk duduk ke tempat duduknya masing-masing, dan Ani di minta mengumpulkan semua hasil diskusi masingmsing kelompok. Lalu setelah seluruh siswa duduk di tempatnya masing-masing dan Ani selesai mengumpulkan hasil diskusi, guru memberi siswa tes formatif 1 yang terdiri dari 5 soal dan waktu pengerjaan 10 menit. Setelah tes selesai terdengan lonceng berbunyi maka, guru meminta siswa untuk menyimpan buku IPA dan dilanjutkan mata pelajaran berikutnya.

Dari hasil kegiatan dan pengamatan tersebut diperoleh datadata sebagai berikut :

\section{Data Aktivitas Belajar Siswa}

Yang menjadi pengamat aktivitas belajar siswa yakni teman sejawat peneliti. Skor Aktivitas Belajar diperoleh dari lembar observasi aktivitas. Pengamatan dilakukan oleh dua pengamat selama 20 menit kerja kelompok dalam setiap KBM atau 40 menit dalam satu siklus. Dengan pengamatan setiap 2 menit, maka nilai maksimum yang mungkin teramati untuk satu kategori aktivitas selama 40 menit adalah 20 kali. Adapun data aktivitas 
yang diperoleh selama 40 menit pada siklus I adalah sebagai berikut

Tabel 4.2 Skor Aktivitas Belajar Siswa

\begin{tabular}{|l|l|l|l|}
\hline \multirow{2}{*}{ Aktivitas } & \multicolumn{2}{|l|}{ Siklus I } \\
\cline { 2 - 4 } & Jumlah & Skor & Persentasi \\
\hline Menulis/membaca & 89 & 22,25 & $45 \%$ \\
\hline Mengerjakan LKS & 28 & 7 & $14 \%$ \\
\hline Bertanya kepada teman & 24 & 6 & $12 \%$ \\
\hline Bertanya kepada guru & 33 & 8,25 & $17 \%$ \\
\hline $\begin{array}{l}\text { Yang tidak relevan dengan } \\
\text { KBM }\end{array}$ & 26 & 6,5 & $13 \%$ \\
\hline JUMLAH & 200 & 50 & $100 \%$ \\
\hline
\end{tabular}

Dari tabel 4.2 diatas diketahui aktivitas belajar siswa masih didominasi oleh kegiatan individualis, secara spesifik tabel 4.1 diatas adalah :

a. Aktivitas menulis/membaca $45 \%$

b. Aktivitas mengerjaka LKS $14 \%$

c. Aktivitas bertanya kepada teman $12 \%$

d. Aktivitas bertanya kepada guru $17 \%$

e. Aktivitas yang tidak sesuai dengan KBM 13\%

Data hasil ketuntasan belajar siswa

Pada hasil formatif siklus I hasil belajar siswa meningkat dari yang sebelumnya nilai rata-rata kelas mencapai 65,8. Hasil tes belajar atau disebut formatif I dapat dilihat pada tabel.. Hasil belajar yang diperoleh pada siklus I selama dua pertemuan disajikan dalam Tabel berikut:
Tabel 4.3 Distribusi Hasil Formatif I

\begin{tabular}{|c|c|c|c|c|}
\hline Nilai & Frekuensi & Rata-rata & $\begin{array}{l}\mathrm{S} \\
\text { Deviasi }\end{array}$ & $\begin{array}{l}\mathrm{K} \\
\text { Klasikal }\end{array}$ \\
\hline 40 & 13 & \multirow{5}{*}{65.8} & \multirow{5}{*}{21.76} & \multirow{5}{*}{$65.78 \%$} \\
\hline 60 & 6 & & & \\
\hline 80 & 14 & & & \\
\hline 100 & 5 & & & \\
\hline Jumlah & 38 & & & \\
\hline
\end{tabular}

Pada Tabel 4.3 tersebut, nilai terendah formatif I adalah 40 sebanyak 31 orang dan nilai tertinggi adalah 100 sebanyak 5 orang, 13 orang mendapat nilai dibawah kriteria ketuntasan atau ketuntasan klasikal adalah sebesar $65,78 \%$. Nilai rata-rata kelas adalah 65,8 dimana berada di atas KKM yang ditetapkan. Data hasil formatif I ini dapat disajikan kembali dalam grafik histogram sebagai berikut:

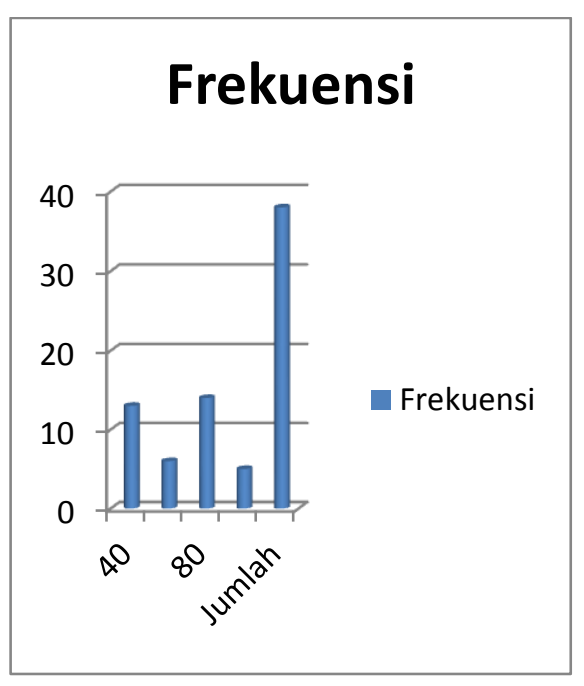

Gambar .4.2 Grafik Data Hasil Formatif I 


\section{Refleksi}

Berdasarkan data tabel 4.3 dan gamabar 4.2 diperoleh bahwa rata-rata formatif 65,8 pada siklus I dengan persentase ketuntasan klasikal sebesar 65,78\%. Hasil tersebut menunjukkan bahwa pada siklus I secara klasikal siswa belum tuntas belajar, karena siswa yang memperoleh nilai $\geq 60$ hanya sebesar $65,78 \%$ lebih kecil dari persentase ketuntasan yang dikehendaki yaitu sebesar $85 \%$. Hal ini disebabkan karena siswa tampak kurang serius selama pembelajaran. Waktu yang diberikan untuk berdiskusi dijadikan oleh siswa sebagai ajang bermainmain. Mungkin hal ini dikarenakan siswa belum benar-benar paham dengan proses belajar dengan penerapan model pembelajaran kooperatif tipe STAD.

Belum tercapainya standar ketuntasan tersebut tidak terlepas dari rendahnya aktivitas belajar siswa. Merujuk pada Tabel 4.1, pada siklus I rata-rata aktivitas I yakni menulis dan membaca memperoleh persentase $\quad 45 \%$. Aktivitas mengerjakan LKS dalam diskusi mencapai $14 \%$. Aktivitas bertanya pada teman sebesar $12 \%$. Aktivitas bertanya kepada guru $17 \%$ dan aktivitas yang tidak relevan dengan KBM sebesar 13\%. Aktivitas membaca memperoleh persentase lebih besar dibandingkan aktivitas mengerjakan. Hal ini menunjukkan bahwa siswa masih kurang kooperatif dalam menyelesaikan LKS yang diberi oleh guru. Besarnya nilai menulis dan membaca ini juga mengindikasikan bahwa siswa belum mempersiapkan diri dari rumah, sehingga pada saat diskusi siswa masih banyak yang membaca dibandingkan mengerjakan LKS. Pada proses pembelajaran masih ditemukan hal-hal yang perlu mendapatkan perhatian berkaitan dengan penelitian tindakan kelas yaitu :

a. Siswa belum melakukan diskusi secara maksimal. Masih ada beberapa siswa yang bermain, dan menjadikan diskusi sebagai ajang bermain. Guru hanya bisa menegur siswa, dan setelah guru pergi siswa kembali melakukan hal yang sama. Ada juga siswa yang aktif selama proses diskusi dilakukan.

b. Waktu yang tersedia belum mampu dimanajemen dengan lebih baik sehingga terkesan terburu-buru untuk menyelesaikan kegiatan pembelajaran, oleh karena itu peneliti harus lebih terampil dan detail dalam mengatur waktu.

c. Pada saat salah satu kelompok membacakan hasil diskusinya, tidak banyak siswa yang mau bertanya ataupun memberikan pertanyaan.

d. Guru belum maksimal dalam menyediakan media ajar, sehingga guru belum dapat memotivasi siswa dengan baik.

\section{Revisi (Tindakan Perbaikan)}

Dari refleksi pada siklus I, maka perlu dilakukan revisi untuk perbaikan pada siklus II, yaitu : 
a. Peneliti menginformasikan bahwa di akhir pertemuan siklus II aka ada tes formatif, dengan harapan agar siswa lebih aktif dalam belajar.

b. Peneliti menegaskan pada siswa yang tidak serius dalam pelaksanaan diskusi, dan siswa yang mengganggu temannya akan dihukum oleh guru, dan bagi kelompok yang paling tertib dan baik hasil diskusinya maka akan di beri hadiah kejutan.

c. Peneliti kembali mendesain pembelajaran dengan lebih detail dalam pembagian waktu sehingga proses belajar dengan menerapkan model pembelajaran kooperatif tipe STAD dapat berjalan dengan baik dan tidak terkesan tergesa-gesa.

d. Peneliti mengikutsertakan siswa dalam penyiapan media, dengan menugaskan setiap kelompok membawa bahan dan alat untuk menunjang pembelajaran di sekolah. Hal ini diharakan mampu menumbuhkan rasa tanggung jawab siswa terhadap pembelajaran dan mampu meningkatkan keseriusan siswa dalam belajar.

\section{Siklus II}

\section{Rencana}

Hal-hal yang dilakukan dalam perencanaan adalah :

a. Menyiapkan Silabus II dan RPP untuk pertemuan 3 dan pertemuan 4

b. Menyiapkan Materi Pelajaran c. Menyiapkan Lembar Kerja Siswa (LKS 2 dan LKS 3)

d. Menyiapkan Lembar Aktivitas Siswa

e. Menyiapkan soal tes hasil belajar siklus II (Formatif II)

f. Memperhatikan refleksi pada siklus I

\section{Kegiatan dan Pengamatan}

Pelaksanaan siklus II adalah sebagai berikut :

\section{Kegiatan pembelajaran 3}

Senin 10 Nopember 2014 peneliti masuk kelas VI SD Negeri 034 Pintupadang Julu .

Ketika guru masuk ke dalam kelas, suasana kelas sangat tenang. Siswa sudah duduk di tempat duduk masing-masing dan telah mengeluarkan buku mata pelajaran IPA mereka. Guru memberikan salam dan siswa menjawab salam guru dengan serentak, guru sudah memperhatikan bahwa keberadan siswa sangat rame, oleh karena itu guru mengabsen siswa dengan memanggil namanya satu-persatu. Setelah mengabsen siswa, guru menginformasikan kepada siswa bahwa materi hari ini yakni perkembangbiakan hewan Vivivar. Setiap

kelompok di beri LKS sebagai bahan diskusi. Setelah membagikan LKS guru memandu siswa dalam penyelesaian LKS. Waktu diskusi diberi 30 menit, dan selama diskusi 2 orang teman sejawat peneliti mengawasi aktivitas belajar siswa. Selama siswa berdiskusi guru bertindak sebagai fasilitator. Guru berkeliling ke setiap kelompok untuk mengawasi jalannya diskusi. Guru lebih memfokuskan perhatiannya pada siswa yang pada siklus I melakukan keributan. Setelah 30 menit berdiskusi guru kemudian meminta siswa mengumpulkan hasil diskusinya. Kemudian guru meminta kelompok 3 untuk mempresentasikan hasil diskusinya. Setelah dibacakan oleh kelompok 3, maka guru memberikan waktu tanya jawab pada siswa. Beberapa siswa bertanya dan kelompok 3 mampu untuk menjawab, tapi untuk 
memperkuat dan memantapkan pemahaman siswa maka guru melakukan penguatan. Setelah melakukan penguatan, guru dan siswa menyimpulkan pembelajaran. Pembelajaran ditutup dengan pemberian tugas kepada siswa untuk membuat rangkuman di rumah. Selanjutnya guru mengajak siswa untuk berdoa sebelum pulang kerumah masing-masing.

\section{Kegiatan pembelajaran 4}

KBM 4 dilakukan pada hari jumat 14 Nopember 2014 pada les ke 1 dan les 2. Saat memasuki ruangan kelas VI, suasana kelas cukup tertib, siswa duduk di kursinya masing-masing dan telah mengeluarkan buku pelajaran IPA mereka. Guru kemudian memberi salam dengan mengucapkan " assalamualaikum anak-anak". Seluruh siswa dengan serentak menjawab salam dengan

mengucapkan "Walaikum salam Buk". Guru kemudian mengabsen siswa dengan memanggil nama siswa satu-persatu.

Setelah mengabsen siswa, guru menginformasikan materi ajar yakni perkembangbiakan hewa Ovovivivar, dan guru juga menjelaskan tujuan pembelajaran kepada siswa. Setelah menjelaskan tujuan pembelajaran, guru memberikan apersepsi yang berhubungan dengan materi ajar dan menjelaskan materi ajar secara singkat kepada siswa. Kemudian guru meminta siswa untuk kembali membentuk kelompok, dan duduk berdasarkan kelompoknya.

Seluruh kelompok tampak sibuk mengikuti bimbingan dan arahan dari guru, berikutnya peneliti membagikan LKS-4, siswa diminta untuk mendiskusikan LKS dan mengerjakannya. Waktu pengerjaan yakni 30 menit. Guru bertindak sebagai fasilitatoir, dan dua orang pengamat mengambil data aktivitas belajar siswa selama berdiskusi. Setelah seluruh siswa menyelesaikan LKS, guru kemudian meminta siswa untuk mengumpulkan hasil diskusinya dan bersama dengan siswa menyimpulkan pembelajaran. 15 menit terakhir peneliti membagikan lembar uji formatif II, uji ini diisaratkan sebagai instrumen untuk mengukur sejauh mana perkembangan belajar siswa pada siklus II khususnya pada hasil belajar dan aktivitas belajar. Setelah lonceng terakhir berbunyi peneliti mengisaratkan pada siswa untuk mengumpulkan lembar formatif II. Selanjutnya pembelajaran diakhiri dengan ucapan salam "selamat pagi anak-anak" siswa menjawab "selamat pagi Buk!!!”.

\section{Data hasil pengamatan aktivitas siswa}

Data aktivitas siswa selama kegiatan belajar mengajar dapat dilihat pada tabel di bawah ini :

\section{Tabel 4.4 Skor Aktivitas Belajar Siswa Siklus II}

\begin{tabular}{|l|l|l|l|}
\hline \multirow{2}{*}{ Aktivitas } & \multicolumn{2}{|l|}{ Siklus II } \\
\cline { 2 - 4 } & Jumlah & Skor & Persentasi \\
\hline Menulis/membaca & 48 & 12 & $27 \%$ \\
\hline Mengerjakan LKS & 72 & 18 & $40 \%$ \\
\hline $\begin{array}{l}\text { Bertanya Kepada } \\
\text { teman }\end{array}$ & 38 & 9,5 & $21 \%$ \\
\hline $\begin{array}{l}\text { Bertanya kepada } \\
\text { guru }\end{array}$ & 14 & 3,5 & $8 \%$ \\
\hline $\begin{array}{l}\text { Yang tidak relevan } \\
\text { dengan KBM }\end{array}$ & 8 & 2 & $4 \%$ \\
\hline JUMLAH & 180 & 45 & $100 \%$ \\
\hline
\end{tabular}

Aktivitas siswa pada siklus II, yang paling dominan dan yang mengalami peningkatan adalah mengerjakan LKS (dari 14\% menjadi 40\%). Hal ini berarti siswa sudah mulai mengerti apa yang harus dikerjakannya di dalam kelompok. Aktivitas menulis/membaca menyusut seiring dengan meningkatnya aktivitas mengerjakan LKS (dari 45 menjadi 27\%). Aktivitas bertanya pada teman dan bertanya pada guru masing-masing $(21 \%)$ dan $(8 \%)$ Hal ini berarti siswa dapat berlatih keterampilan 
kooperatif dengan baik, lebih bisa menghargai pendapat siswa lain dan lebih interaktif dalam kegiatan belajarnya (berpusat pada siswa). Sedangkan perilaku yang tidak relevan mengalami penurunan yaitu (dari 13\% menjadi 4\%). Hal ini berarti siswa lebih bisa memanfaatkan waktunya untuk hal yang positif di dalam kelas dan dapat mengurangi kegiatan yang negatif seperti bergurau di dalam kelas.

\section{Data hasil ketuntasan belajar siswa}

Data-data formatif I dianalisis, sehingga mendapat suatu gambaran tentang keberhasilan siswa. Untuk memperbaiki hasil belajar siswa, peneliti memberikan suatu gambaran hasil belajar siswa pada formatif I sesama peneliti/guru kemudian didiskusikan untuk mengambil tindakan berikutnya pada siklus II. Diskusi tersebut juga dilakukan terhadap pembimbing PTK agar pada tindakan berikutnya aktivitas siswa semakin baik dan hasil belajarnya juga lebih baik. Uraian di atas menyatakan bahwa pada Siklus I indikator keberhasilan belum tercapai karena terdapat 13 siswa yang belum tuntas nilainya. Oleh karena itu perlu adanya suatu tindakan pada siklus II agar hasil belajar siswa dapat ditingkatkan dan mencapai indikator keberhasilan dengan ketuntasan klasikal mencapai maksimum. Akhir KBM ke empat dilakukan tes hasil belajar atau disebut formatif II, datanya dapat dilihat pada tabel 4.5. berikut :

Tabel 4.5. Distribusi Hasil Formatif II

\begin{tabular}{|l|l|l|l|l|}
\hline Nilai & Frekuensi & Rata-rata & $\begin{array}{l}\text { S } \\
\text { Deviasi }\end{array}$ & $\begin{array}{l}\text { K } \\
\text { Klasikal }\end{array}$ \\
\hline 60 & 3 & & & \\
\cline { 1 - 2 } & 20 & \multirow{2}{*}{86.32} & 12.39 & $100 \%$ \\
\hline 100 & 15 & & & \\
\cline { 1 - 2 } Jumlah & 38 & & & \\
\hline
\end{tabular}

Merujuk pada Tabel 4.5, nilai terendah untuk formatif II adalah 60 sebanyak 1 orang dan tertinggi adalah 100 sebanyak 15 orang. Semua siswa telah tuntas belajar mendapat nilai kriteria ketuntasan minimum atau ketuntasan klasikal adalah sebesar $100 \%$. Data hasil formatif II ini dapat disajikan kembali dalam grafik histogram sebagai berikut:

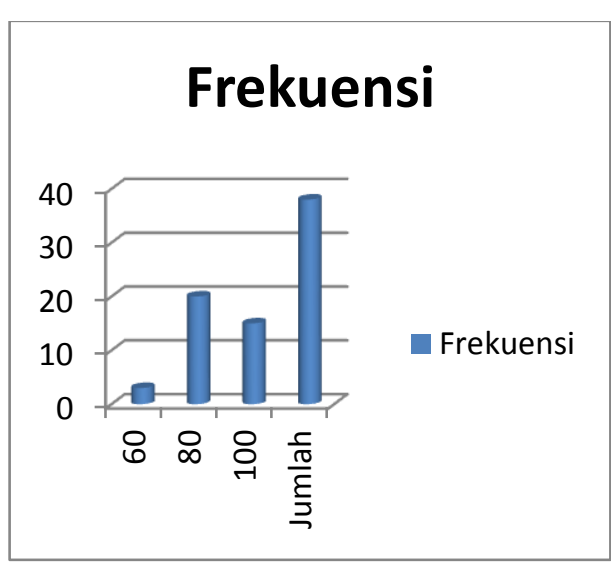

Gambar .4.3 Grafik Data Hasil
Formatif II 


\section{Refleksi}

Hasil belajar siswa diakhir siklus II telah mencapai ketuntasan klasikal $100 \%$, yang berarti seluruh siswa telah memperoleh nilai tuntas dengan mendapatkan nilai di atas KKM. Dengan demikian tindakan yang diberikan pada siklus II telah berhasil memberikan perbaikan hasil belajar pada siswa. Hal ini dipengaruhi beberapa faktor diantaranya adalah sebagai berikut:

1. Diskusi siswa sudah mengalami peningkatan dilihat dari meningkatnya aktivitas mengerjakan dari pada menulis dan membaca, dan lebih besarnya persentase bertanya pada teman dari pada bertanya pada guru. Hal ini mengindikasikan bahwa nilai kooperatif siswa sudah meningkat dari pada siklus I.

2. Peneliti cukup baik dalam mengelolah waktu, sehingga pada siklus II tampak proses pembelajaran lebih terstruktur dan siswa tidak tergesa-gesa dalam menyelesaikan LKS

3. Dengan diikutsertakannya siswa dalam penyedian bahan dan alat yang digunakan utuk melakukan praktek di sekolah, maka siswa merasa lebih bertanggung jawab terhadap tugas yang dibebankan padanya seperti LKS yang harus didiskusikan di dalam kelompok.

\section{Revisi (Tindakan Perbaikan)}

Pada siklus II guru telah menerapkan model pembelajaran Kooperatif Tipe STAD dengan baik dan dilihat dari aktivitas siswa serta hasil belajar siswa pelaksanaan proses belajar mengajar sudah berjalan dengan baik. Maka tidak diperlukan revisi terlalu banyak, tetapi yang perlu diperhatikan untuk tindakan selanjutnya adalah memaksimalkan dan mempertahankan apa yang telah ada dengan tujuan agar pada pelaksanaan proses belajar mengajar selanjutnya penerapan pembelajaran Kooperatif Tipe STAD dapat meningkatkan proses belajar mengajar sehingga tujuan pembelajaran dapat tercapai dengan maksimal.

\section{SIMPULAN DAN SARAN Simpulan}

Data-data tes hasil belajar dan aktivitas belajar siswa terhadap model pembelajaran kooperatif tipe STAD selama kegiatan belajar mengajar, kemudian dianalisis, sehingga dapat disimpulkan sesuai dengan rumusan masalah.

a. Pembelajaran kooperatif tipe STAD dapat meningkatkan aktivitas belajar siswa pada mata pelajaran IPA di kelas VI SD Negeri 034 Pintupadang Julu.

b. Pembelajaran kooperatif tipe STAD dapat meningkatkan prestasi belajar siswa pada mata pelajaran IPA di kelas VI SD Negeri 034 Pintupadang Julu. 
Dengan demikian maka tindakan guru dalam menerapkan model pembelajaran kooperatif tipe STAD pada bidang studi IPA di sini telah berhasil mencapai tujuan yang diinginkan, dimana mampu meningkatkan aktivitas belajar siswa yang bermuara pada peningkatan prestasi belajar siswa.

\section{Saran}

Dari hasil yang diperoleh dalam penelitian ini, maka beberapa saran yang diajukan yaitu:

a. Dalam penerapan model pembelajaran STAD hendaknya dibuat LKS yang menunjang aktivitas diskusi siswa dan untuk memotivasi siswa agar lebih aktif dalam diskusi.

b. Untuk menerapkan model pembelajaran STAD maka guru hendaknya mampu memanajemen waktu sebaik mungkin, agar tidak terkesan terburu-buru.

c. Dapat digunakan sebagai bahan acuan bagi teman guru lainnya sebagai alternatif penyelesaian masalah ketika mengalami masalah yang sama dengan latar belakang pada penelitian ini.
DAFTAR RUJUKAN

Arikunto,S.(1992).

Prosedur

Penelitian Suatu

Pendekatan Praktek.

Jakarta: Rineka Cipta.

Aqib, Zainal. (2006). Penelitian

Tindakan Kelas.

Bandung: $\quad$ Yrama

Widya.

Hamalik, Oemar. 1995. Kurikulum dan Pembelajaran. Jakarta: Bumi Aksara.

Nasution. 1995. Didaktik Asas-asas Mengajar. Jakarta: Bumi Akasara.

Syah, M. 1995. Psikologi Pendidikan dengan Pendekatan Baru. $\quad$ Bandung: Remaja Rosdakarya

Tarigan,S.Pd,

Mariani.2011.Meningkat kan Hasil Belajar Siswa Melalui Model Pembelajaran Kooperatif Tipe STAD Selama Kegiatan Belajar Mengajar Pada Materi Pokok Artikulasi Bunyi Dan Melafalkan Bahasa Indonesia Baku Di Kelas I AK-1 SMKN 1 Kabanjahe. Kabanjahe. 